\title{
Phytochemical Analysis and Antimalarial Activity of Usnea sp. from South Sulawesi against Plasmodium falciparum
}

\author{
Iwan Dini $^{1 *}$, Maryono ${ }^{1}$, Akmal $^{2}$ and Sitti Hajar ${ }^{1}$ \\ ${ }^{1}$ Chemistry Department, Mathematics and Natural Science, State University of Makassar, \\ Makassar, Indonesia \\ ${ }^{2}$ Chemistry Laboratory, Mathematics and Natural Science, State University of Makassar, \\ Makassar, Indonesia \\ *Corresponding author
}

A B S T R A C T

Usnea sp is known in south Sulawesi as taianging plants. It is one of the kind of lichen species. Local communities in Gowa, south Sulawesi particularly at Malino district were used for medical purposes. The aim of this research is determining the chemical compound

Keywords

Lichenes, Taianging

Usnea sp.,

Phytochemical,

Antimalarial,

Plasmodium

falciparum,

Malino, Extraction.

Article Info

Accepted:

16 July 2017

Available Online:

10 September 2017 of lichen Usnea sp extract and its potential as anti malariai medication. Extracts are obtained by fractional extraction with maceration method using organic solvent. Phytochemical test with chemical reagent and antimalarial potential test through observation of ant plasmodium activity strains of plasmodium falciparum (FCR-3) measured on $\mathrm{IC}_{50}$. The result has shown that Usnea sp extract from Lompobattang mountain contains of alkaloid and saponin compound in methanol extract. In ethyl acetate extract that contains of alkaloid, flavonoid, Quinone and triterpenoid, has showed weak indication. In methanol extract, contains of flavonoid and antarquinon compound. In chloroform extract that contains of saponin, polyphenol, flavonoid antarquinon, triterpenoid and steroid compound. Medium indication in methanol and ethyl acetate extract that contains of polyfhenol compound, strong indication has showed anti plasmodium activity in $\mathrm{IC}_{50}$ for $\mathrm{n}$-hexane, chloroform, ethyl acetate and methanol extract respectively $977.24,426.58,5.19$ and $3.14 \mu \mathrm{g} / \mathrm{ml}$ for 24 hours incubation and 32, 36, 22, 23, 3, 74 and $3.42 \mu \mathrm{g} / \mathrm{ml}$ for 72 hours incubation. This research conclude that the ethyl acetate and methanol extract of Usnea sp contains polyphenol compound with strong indication and both has antimalarial potential as antiplasmodium activity with very good category.

\section{Introduction}

Research of secondary metabolite compounds efficacious in tropical forest species Indonesia is still not significant with the diversity of plants in Indonesia. This demonstrates the greatness of the potential of Indonesia's tropical plant diversity. For instance, the tropical forest plants in Malino Gowa regency South Sulawesi is still very few even classified as not reached as the object of research chemistry of natural product, whereas the results of research in this field has much to contribute to the development of science, especially in Indonesia. The ongoing research of Indonesian tropical forests will certainly continue to contribute greatly in the development of organic chemistry of natural 
product and related technologies in the future (Sjamsul A. Achmad, 2006).

In the tropical forest of Lompobattang Malino mountain region of South Sulawesi province found many lichen species that are used by the local people as a source of medicines are found. For instance, blepharea motyka and Usnea blepharea that used as leprosy drugs, cough medicines and medicines are used remove small flesh that grows on the skin or warts. The investigation of the chemical content of Talus into this lichen species, found difractic acid, dibenzofuran, (-) -usnat acid, eumitrin M, eumitrin A1 and eumitrinM have activity as antimalarial (Maulidiyah, 2011).

Lichen until now in some countries is still widely used for some treatments such as arthritis, constipation, chemotherapy, external wounds, microbial infections, worms and lice. This is certainly due to the presence of active chemical compounds in lichen known as antibacterial, antifungal, antiviral, antitumor, anticancer, antioxidant, anti-inflammatory, antiprotozoal, analgesic and antipyretic, and anthelmintic. Thus, lichen can be developed prospected as a source of modern drug discovery (Eris Septiana, 2011).

One of the great opportunities in line with the potential of Malino lichen this is, the number of malaria disease which is one of the infectious diseases spread throughout the world is still quite large. From 300-500 million clinical cases there are 1.5 million deaths every year (Biagini et al., 2003). The efforts from the community are using mosquito nets, installing of wire netting, using repellent and wear long-sleeved shirts when at the outdoors in night. However such did not have an influence on the existence of cases of malaria in an area except for the use of the repellent (Wahyu Retno Widyasari et $a l ., 2014)$. Ensure that the response to this disease are still experience much problems as seen from the numbers of malaria deaths in some countries remains high, including in Indonesia Among the causes is resistance to antimalarial drugs, drug resistance to malarial parasite species causes some malaria treatment methods to be less effective (Jeanne Poespoprodjo, 2011).

Usnea sp. is one of the lichen species, it has much found in the mountainous area of Lompobattang, South Sulawesi, utilized by the local community as a medicinal plant. Reportedly some lichen species of the genus Usnea metabolize many secondary metabolites are efficacious among them compound of eumitrinA1, eumitrinA3, eumitrinB1 and B2 from Usnea baileyi (Laily B. din, et. al., 2010). EumitrinA1 which has a cytotoxic activity against murine $\mathrm{P}_{388}$ cells with the $\mathrm{IC}_{50}$ value of $4.5 \mu \mathrm{g} / \mathrm{mL}$ (Maulidiyah et al., 2007). EumitrinM which have antimalarial activity against $P$. falciparum parasite with $\mathrm{IC}_{50}$ values $2 \times 10^{-7} \mathrm{M}$ found from Usneablepharea Motyka (Maulidiyah, 2011).

Almost all compounds are bioactively that source from natural ingredients reported from isolation results always proceeded by traceability of bioactive properties of plant nut extracts. It has become a common method of research to discovery of bioactive compounds nutritious drugs from natural materials preceded by the efficacy test extracts of these natural product. Among them is the n-hexane extract of the bark of Asamkandis are bioactive against $P$. falciparum with $\mathrm{IC}_{50} 2.79 \pm 0.10 \mu \mathrm{g} / \mathrm{mL}$ (Syamsudin et al., 2007). Fraction of ethyl acetate of variegated leaves are bioactive against $P$. falciparum $3 \mathrm{D} 7$ strain with $\mathrm{IC}_{50} 17$ $\mu \mathrm{g} / \mathrm{mL}$ and found 3,22,23-trihidroksiolean12-ene that are active against $P$. falciparum 3D7 strain with a value of $\mathrm{IC}_{50} 4.3 \mu \mathrm{g} / \mathrm{mL}$ (Tati Herlina et al., 2011). Therefore, this study was conducted to know the potential of 
phytochemicals of lichen extract and antimalarial activity potential of Usnea sp. growing in the Malino forest of Gowa regency of South Sulawesi in the context of the discovery of anti-malarial bioactive compounds.

\section{Materials and Methods}

The study was observational is observing potential anti-malarial Usnea sp. The plant material Usnea sp. Taken and collected from the mountains of Lompobantang Malino Gowa District, South Sulawesi Indonesia. The specimens were identified in Bogorieses LIPI Bogor Indonesia. Reparations, preparation of extracts and phytochemical testing with reagents were carried out at the Chemistry Research Laboratory of FMIPA UNM including alkaloid, saponin, polyphenol, flavonoid, quinone and triterpenoid/steroid tests (Harborne, 1996). Anti-malarial activity test was measured as activity against Plasmodium falciparum culture strain FCR-3 (Trager and Jensen, 1976). Plasmodium activity data in the form of relationships percent inhibition and concentration of the extract further analyzed to obtain $\mathrm{IC}_{50}$ $(\mu \mathrm{g} / \mathrm{mL})$ using probit analysis. Descriptive presentation of data generated each for mean percent inhibition of $P$. falciparum (FCR-3) in the form of charts respectively at $24 \mathrm{~h}$ incubation and $72 \mathrm{~h}$ incubation. The phytochemical and $\mathrm{IC}_{50}$ values in $\mu \mathrm{g} / \mathrm{mL}$ extract Usnea sp. against $P$. falciparum (FCR3) are presented in tabular form.

\section{Results and Discussions}

Phytochemical test for the identification of secondary metabolites content of each extract (n-hexane, chloroform, ethyl acetate, and methanol) lichen Usnea sp. as where in table 1, provide information that Usnea $\mathrm{sp}$. Growing in the Malino region of Lompobattang mountains metabolizes secondary metabolite compounds such as alkaloids, saponins, polyphenols, flavonoids, quinones, triterpenoids and steroids. The results of strong, moderate, and weak indication tests were observed from the strong color changes formed in the test. The polyphenol test showed strong indications in the presence of brownish-red and pink color changes in the controls. Indication is on the steroid test with the formation of a bluish green color, triterpenoid test in the presence of pink colored as well as on flavonoids test indication is in the presence of color changes extract tested to red.

The identification through TLC of each extract as in figure 1, from chromatogram of a $254 \mathrm{~nm}$ UV light was seen in the hexane extract there was one spot, on chloroform extract two spots, ethyl acetate extract and methanol each had four stain spots. There are four types of luminescence under UV 254: white, yellow, red, and brown.

Antimalarial activity test data created in the form of a diagram plotted between concentration and average percent inhibition as in figure 2. Test antiplasmodium activity with Giemsa staining, indicating the number of parasite-infected erythrocytes were counted then converted as a percentage inhibition. The calculation of the average percentage of inhibition of parasitemia in each extract concentration generally indicates an increase in the percentage of inhibition. However, there is a large increase difference between ethyl acetate and methanol extracts with nhexane and chloroform both at the 24-hour cetubation and the 72-hour diingkubasi. Moreover, the observed data show that the percentage of inhibition of ingkubasi 72 hour period is greater than the incubation period of 24 hours which indicates that there is influence of concentration and a percentage inhibition ingkubasi against parasitemia on each extract Usnea sp. These results also 
showed that the ethyl acetate extract and methanol Usnea sp. is an extract that has the highest antimalarial activity compared to extract $\mathrm{n}$-hexane and chloroform as to which is shown in figure 2. Therefore, lichen extract Usnea sp. has potential as anti-malarial especially ethyl acetate extract and methanol extract.

The result of the calculation of the IC ${ }_{50}$ (the dose that indicates the number of doses required to inhibit growth by $50 \%$ parasitaemia). As in table 2, showing the second extract has $\mathrm{IC}_{50}$ lower than the n- hexane extract and chloroform. Activities anti-plasmodium ethyl acetate and methanol extracts against $P$. falciparum FCR-3 with probit analysis obtained $\mathrm{IC}_{50}$ value each of $5.19 \mu \mathrm{g} / \mathrm{mL}$ and $3.14 \mu \mathrm{g} / \mathrm{mL}$ for 24 hours incubation and $3.76 \mu \mathrm{g} / \mathrm{mL}$ and $3,42 \mu \mathrm{g} / \mathrm{mL}$ for a 72 hour citation.

The content Phytochemical of the extracts Usnea sp. which is intended as a strong, moderate and weak indication can illustrate the content of the intended compound of the test type is more or more dominant.

Table.1 Phytochemical test results of several extracts of Usnea sp.

\begin{tabular}{|c|c|c|c|c|c|c|c|c|}
\hline \multirow{2}{*}{ Extract } & \multicolumn{2}{|c|}{ Alkaloid } & \multirow{2}{*}{-Saponin } & \multirow{2}{*}{$\begin{array}{l}\text { Tannin/ } \\
\text { polyphenol }\end{array}$} & \multirow{2}{*}{ Flavonoid } & \multirow{2}{*}{ quinone } & \multirow{2}{*}{ Triterpenoid } & \multirow{2}{*}{ Steroid } \\
\hline & Meyer & Wagner & & & & & & \\
\hline N-Hexane & - & - & - & - & - & - & - & - \\
\hline Chloroform & - & - & ++ & ++ & ++ & ++ & ++ & ++ \\
\hline Ethyl acetate & - & + & - & +++ & + & + & + & - \\
\hline Methanol & + & + & + & +++ & ++ & ++ & - & - \\
\hline
\end{tabular}

Information; (-): negative; $(+)$ : Weak indication; $(++)$ : medium indication; $(+++)$ : strong indication

Table.2 Values of $\mathrm{IC}_{50}(\mu \mathrm{g} / \mathrm{mL})$ Usnea extract sp. in culture $P$. falciparum (FCR-3)

\begin{tabular}{lllll}
\hline \multirow{2}{*}{ Incubation period } & \multicolumn{4}{c}{ IC $_{\mathbf{5 0}}(\boldsymbol{\mu g} / \mathbf{~ m L})$ Extract } \\
\cline { 2 - 5 } & n-hexane & Chloroform & Ethylacetate & Methanol \\
\hline 24 hours & 977.24 & 426,58 & 5.19 & 3.14 \\
\hline 72 hours & 32.36 & 22.23 & 3.76 & 3.42 \\
\hline
\end{tabular}

Fig.1 Profile chromatogram extract Usnea sp. eluent ethyl acetate: n-hexane 6: 4, (A) at $254 \mathrm{~nm} \mathrm{UV}$ and (B) at $365 \mathrm{~nm} \mathrm{UV}$

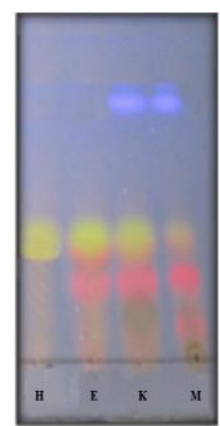

(A)

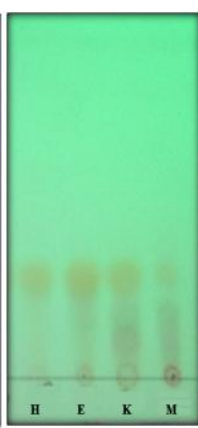

(B)

(H: n-hexane extract; E: ethylacetate extract; K: chloroform extract; M: methanol extract) 
Fig.2 Mean percent percentage of Usnea sp. inhibition resistant strains of $P$. falciparum to Chloroquine (FCR-3) incubate 24 hours (A), 72-hour incubation (B)

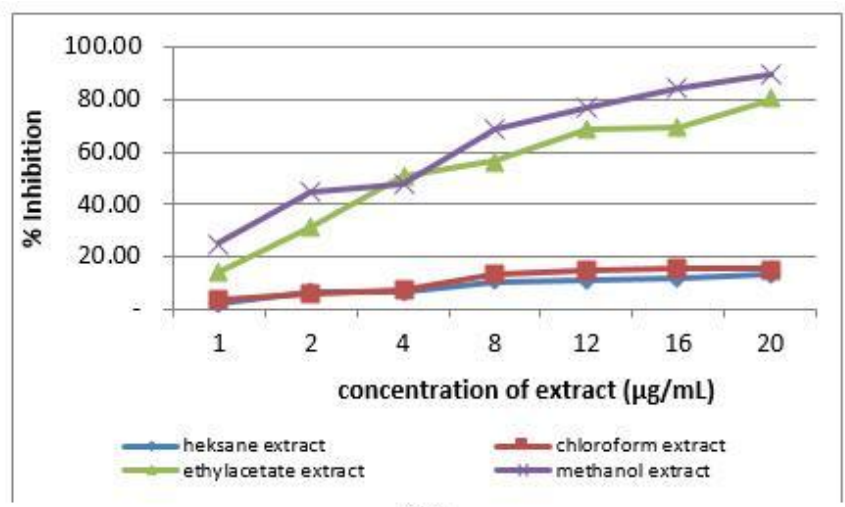

(A)

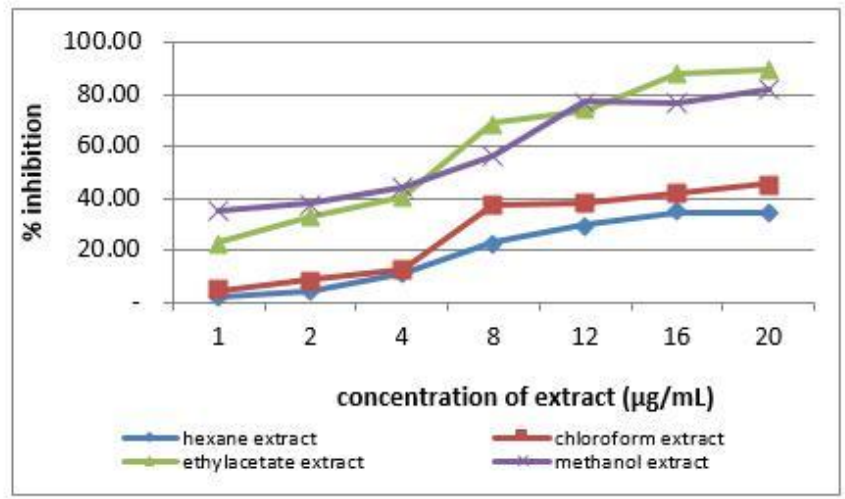

(B)

However, it does not close the possibility of unpredictable compound content due to the sensitivity level of the test reagent to the level of the test compound so that only at a certain level can detect the content of the compound (Table 1), that the n-hexane extract does not show any chemical components tested, On the ethyl acetate extract for the Meyer reagent is negative but for Wagner reagent reacts positively.

White glow on KLT test results with $254 \mathrm{~nm}$ UV light stain impression is suspected to be a polyphenol compound, the luminescence supposedly as quinone and derivative compounds, while brown color is suspected as alkaloids in the presence of chromophores. While yellow luminescence is thought to be flavonol containing three or five hydroxyl groups. From the chromatogram shows the difference in the number of compounds each extract, showed that extraction fractionation were made to extract Usnea sp. It can separate compound components. Indications of polyphenol compounds with a strong indication of ethyl acetate and methanol extracts were confirmed from chromatograms with the highest white luminescence suspected as polyphenolic compounds. From the TLC chromatogram shows the presence of components that glow under UV light. It is understood that the phenolic/polyphenol secondary metabolite compounds including flavonoids glow strongly under UV light. From the literature study it was found that chemotaxonomy, lichen plants generally show unique metabolites derived from the metabolic group which is a phenol and polyphenol compounds such as depsidone, dibenzofuran and hidroxanton (Ingolfsdottir, 
2002). Even known some xanton compounds have cytotoxic activity against various types of cancer cells and some even have antimalarial activity (Likhitwitayawuid, 1998). Some phenolic acid compounds are also found in lichen groups such as picrolisenic acid, vireneic acid, usnat acid, orselinic acid, polyporic acid, and teleporic acid (Veranja Karunaratne, 2005). Also found eumitrinM as antimalarial of known structure is a group of polyphenolic compounds (Maulidiyah, 2011).

Antimalarial activity test created data in the form of a diagram plotted between concentration and average percent inhibition as in figure 2. Test anti-plasmodium activity with Giemsa staining, indicating the number of parasite-infected erythrocytes were counted then converted as a percentage inhibition. The calculation of the average percentage of inhibition of parasitaemia in each extract concentration generally indicates an increase in the percentage of inhibition. However, there was a large increase difference between ethyl acetate and methanol extracts with nhexane and chloroform both at 24-hour cycles and 72-hour to be incubate. Moreover, the observed data show that the percentage of inhibition of incubate 72 hour period is greater than the incubation period of 24 hours which indicates that there is influence of concentration and a percentage inhibition incubate against parasitaemia on each extract Usnea sp. These results also showed that the ethyl acetate extract and methanol Usnea sp. is an extract that has the highest antimalarial activity compared to extract n-hexane and chloroform as to which is shown in figure 2 . Therefore, lichen extract Usnea sp. has potential as anti-malarial especially ethyl acetate extract and methanol extract.

Antimalarial activity test data created in the form of a diagram plotted between concentration and average percent inhibition as in figure 2. Test anti-plasmodium activity with Giemsa staining, indicating the number of parasite-infected erythrocytes was counted then converted as percentage inhibition. The calculation of the average percentage of inhibition of parasitaemia in each extract concentration generally indicates an increase in the percentage of inhibition. However, there is a large increase difference between ethyl acetate and methanol extracts with nhexane and chloroform both at the 24-hour and the 72-hour incubating. Moreover, the observed data showed that the percentage of inhibition of incubate 72 hour period is greater than the incubation period of 24 hours which indicates that there is influence of concentration and a percentage inhibition incubation against parasitaemia on each extract Usnea sp. These results also showed that the ethyl acetate extract and methanol Usnea sp. is an extract that has the highest antimalarial activity compared to extract nhexane and chloroform as to which is shown in figure 2 . The results obtained show that the activity against Plasmodium of ethyl acetate and methanol extracts Usnea sp. in the very good category while to extract n-hexane and chloroform Usnea sp. in the inactive category (Trager and Jensen, 1976).

Therefore, lichen extract Usnea sp. has potential as anti-malarial especially ethyl acetate extract and methanol extract. Potential ethyl acetate and methanol extracts Usnea sp. Malino origin Lompobattang mountains as anti-malarial parasite test against $P$. falciparum FCR-3 from the $\mathrm{IC}_{50}$ values (the dose that indicates the number of doses required to inhibit growth by 50\% parasitaemia) as in table 2 , statistically by probit analysis obtained dose $\mathrm{IC}_{50}$ value each of $5.19 \mu \mathrm{g} / \mathrm{mL}$ and $3.14 \mu \mathrm{g} / \mathrm{mL}$ for 24 hours incubation and $3.76 \mu \mathrm{g} / \mathrm{mL}$ and $3.42 \mathrm{mg} \mathrm{mL}$ to incubation about 72 hours. The potential for anti-malarial activity against the parasite plasmodium of ethyl acetate and methanol extracts Usnea sp. The origin of Malino forest in Gowa regency of South Sulawesi province 
is suspected by the presence of phenol and polyphenol compounds such as depsida, depsidon, dibenzofuran, hidroxanton and eumitrin derivatives as found in several other lichen sepsions (Maulidiyah, 2011 and Trager, W and Jensen, J.B., 1976). The content of alkaloid compounds, saponins, polyphenyls, flavonoids and interquinones in methanol extract Usnea sp. (Table 1), which has potential as an antimalarial compound as the ethanol extract of seeds mahogany (Swietenia macrophylla), which are toxic to larvae of Aedes aegypti with $\mathrm{LC}_{50}$ at $6 ; 12$; 18 ; and 24 respectively at $921.55 \mathrm{ppm}, 358.09$ ppm; 221.60 ppm; and 142.14 ppm (RoniKoneri and Hanny Hesky Pontororing, 2016). Phenol group also reported to be bioactive flavonoids against $P$. falciparum parasite with $\mathrm{IC}_{50} 4.40 \mu \mathrm{g} / \mathrm{mL}$ (Inga Kohlera et al., 2002).

The conclusion from this study is the extract of ethyl acetate and methanol Usnea sp. from Lompo Battang mountains has potentially excellent antimalarial activity with $\mathrm{IC}_{50}$ respectively 5.19 and $3.14 \mu \mathrm{g} / \mathrm{mL}$ for 24 hours of incubation and 3.76 and $3.42 \mu \mathrm{g} / \mathrm{mL}$ for 72 hours incubation and it contain much polyphenol group compounds. For further research it is recommended to isolate and locate the structures of chemical compounds from the group of chemical compounds disclosed through by phytochemical test results above and particularly to discover the structure of the active compound as an antimalarial in lichen Usnea sp.

\section{References}

Biagini, G. A., O’Neill, N.P.M., Ward, S.A., 2003. Antimalarial Chemotherapy; Young Guns or Back to the Future. Trends in Parasitol, 19(11): 479-487.

Eris Septiana, 2011. Potensi Lichen Sebagai Sumber Bahan Obat: Suatu Kajian Pustaka, JurnalBiologi, 15(1): 1-5.
Harborne, J., 1996. Metode Fitokimia; Penuntun Cara Modern Menganalisis Tumbuhan. Cetakankedua. Terjemahan Padmawinata, K. dan I. Soediro. Bandung: Penerbit ITB.

Inga Kohlera, Kristina Jenett-Siemsa, Karsten Siemsb, Marco Antonio Hernándezc, Ricardo A. Ibarrac, Walter G. Berendsohnd, Ulrich Bienzlee, and Eckart Eicha, 2002. In vitro Antiplasmodial Investigation of Medicinal Plants from El Salvador. Z. Naturforsch, 57(c), 277-281.

Ingolfsdottir, K., 2002. Molecules Interest Usnic Acid. Phytochemistry, 6(1):723736.

Jeanne, R., Poespoprodjo, 2011.Skrining Malaria dan Pengobatan yang Efektif. Buletin Jendela Data dan Informasi Kesehatan Epidemologi Malaria di Indonesia, (Triwulan I): 29-33.

Laily B. din, Zuriati Zakaria, Mohd Wahid Samsudin and John A. Elix, 2010. Chemical Profile of Compounds from Lichens of Bukit Larut, Peninsular Malaysia. Sains Malaysiana, 39(6): 901-908.

Likhitwitayawuid, K., 1998. Antimalarial Xanthones from Garcinia Cowa. PlantaMedica, 6(4):70-72.

Maulidiyah, 2011. Isolasi dan Penentuan Struktur Serta Uji Bioaktivitas Senyawa Kimia dari Ekstrak Aseton Lichen Usnea Blepharea Motyka Dan Usnea Flexuosa Tayl [Disertasi]. Jakarta: Universitas Indonesia.

Maulidiyah, A., Herry Cahyana, Wahyudi Priyono Suwarso, Muhammad Nurdin, 2007. Isolation and Structure Elucidation of Eumitrin A1 from Lichen Usneablepharea Motyka and Its Cytotoxic Activity. Int. J. Pharm Tech Res, 8(4): 782-789.

Roni Koneri, Hanny Hesky Pontororing, 2016. Assay of Mahagony (Swietenia macrophylla) Seed Extract on Larvae of 
Aedesaegyptias Dengue Hemorrhagic Fever Vector. Media Kesehatan Masyarakat Indonesia (MKMI), 12(4): 216-223.

Sjamsul A. Achmad., 2006. Hakekat Perkembangan Kimia Organik Bahan Alamdari Tradisionalke Moderen. Akta Kimindo, 1(2): 55-66.

Syamsudin, Soesanto Tjokrosonto, Subagus Wahyuono, dan Mustofa, 2007. Aktivitasantiplasmodiumdariduafraksie kstrak n-heksanakulitbatangasamkandis (Garcinia parvifolia Miq). Majalah Farmasi Indonesia, 18(4): 210-215.

Tati Herlina, Unang Supratman, Anas Urbanas, Supriyatna Sutardjo, Noor Rain Abdullah, dan Hideo Hayashi, 2011. Triterpenoid Pentacyclic
Antimalarial Activity from the Leaves of Erythrina variegate. Jurnal ILMU DASAR, 12(2): 161-166.

Trager, W., and Jensen, J.B., 1976. Human Malaria Parasites in Continuous Culture. Journal Science, 19(3): 673 676.

Veranja Karunaratne, 2005. Review, Lichen s: A Chemically Important Biota, Journal Natn, Sci., Foundation Srilanka, 33(3): 169-186.

Wahyu Retno Widyasari, Hasanuddin Ishak, Agus Bintara Birawida, 2014. Upaya Pencegahan Gigitan Nyamuk Dengan Keberadaan Kasus Malaria. Media Kesehatan Masyarakat Indonesia (MKMI), 10(3): 140-145.

\section{How to cite this article:}

Iwan Dini, Maryono, Akmal and Sitti Hajar. 2017. Phytochemical Analysis and Antimalarial Activity of Usnea sp. from South Sulawesi against Plasmodium falciparum. Int.J.Curr.Microbiol.App.Sci. 6(9): 1653-1660. doi: https://doi.org/10.20546/ijcmas.2017.609.203 